\title{
Development and Investigation of Polyaniline Micro/nanocomposites that Possess Moderate Conductivity, Dielectric and Magnetic Properties
}

\author{
By Sook-Wai Phang and Noriyuki KURAMOTO*
}

\begin{abstract}
As a nano-material possessing moderate conductivity, magnetic and dielectric property, novel hexanoic acid doped polyaniline (PAni/HA) micro/nanocomposites containing $\mathrm{TiO}_{2}$ and $\mathrm{Fe}_{3} \mathrm{O}_{4}$ were prepared by template free method under various polymerization conditions. FT/IR spectra of $\mathrm{PAni} / \mathrm{HA} / \mathrm{TiO}_{2}$ and $\mathrm{PAni} / \mathrm{HA} / \mathrm{TiO}_{2} / \mathrm{Fe}_{3} \mathrm{O}_{4}$ indicated the peaks are derived from PAni/HA. The X-ray diffraction patterns of $\mathrm{PAni} / \mathrm{HA} / \mathrm{TiO}_{2}$ and $\mathrm{PAni} / \mathrm{HA} / \mathrm{TiO}_{2} / \mathrm{Fe}_{3} \mathrm{O}_{4}$ clearly showed the existence of both $\mathrm{TiO}_{2}$ and $\mathrm{Fe}_{3} \mathrm{O}_{4}$. Nanorods/tubes shown in the SEM images indicated that PAni/HA, PAni/HA/TiO 2 and $\mathrm{PAni} / \mathrm{HA} / \mathrm{TiO}_{2} / \mathrm{Fe}_{3} \mathrm{O}_{4}$ micro/nanocomposites exhibited polymerization through elongation. The diameters of PAni/HA nanorods/tubes increased from $150-180 \mathrm{~nm}$ to $180-200 \mathrm{~nm}\left(\mathrm{PAni} / \mathrm{HA} / \mathrm{TiO}_{2}\right.$ and $\left.\mathrm{PAni} / \mathrm{HA} / \mathrm{TiO}_{2} / \mathrm{Fe}_{3} \mathrm{O}_{4}\right)$ after addition of $\mathrm{Fe}_{3} \mathrm{O}_{4}$ and $\mathrm{TiO}_{2}$. PAni/HA, PAni/HA/TiO 2 and $\mathrm{PAni} / \mathrm{HA} / \mathrm{TiO}_{2} / \mathrm{Fe}_{3} \mathrm{O}_{4}$ synthesized at $0{ }^{\circ} \mathrm{C}$ resulted large amount of nanorods/tubes compared with those synthesized at $25^{\circ} \mathrm{C}$. PAni/HA polymerized at low temperature exhibited higher conductivity $\left(1.0 \times 10^{-3} \mathrm{~S} / \mathrm{cm}\right)$ compared with PAni/HA polymerized at higher temperature $\left(7.0 \times 10^{-4} \mathrm{~S} / \mathrm{cm}\right)$. The conductivities of the PAni/HA/ $/ \mathrm{TiO}_{2}$ and $\mathrm{PAni} / \mathrm{HA} / \mathrm{TiO}_{2} / \mathrm{Fe}_{3} \mathrm{O}_{4}$ were relatively low $\left(3.3-4.2 \times 10^{-4} \mathrm{~S} / \mathrm{cm}\right)$ after addition of $\mathrm{TiO}_{2}$ and $\mathrm{Fe}_{3} \mathrm{O}_{4}$. PAni/HA/TiO$/ \mathrm{Fe}_{3} \mathrm{O}_{4}$ micro/nanocomposites synthesized at $0{ }^{\circ} \mathrm{C}$ exhibited higher magnetization $(\mathrm{Ms}=7.7 \mathrm{emu} / \mathrm{g})$ compare with micro/nanocomposites that synthesized at $25^{\circ} \mathrm{C}(\mathrm{Ms}=4.7 \mathrm{emu} / \mathrm{g})$. TGA characterizations of the micro/nanocomposites were also being discussed in this paper.

KEY WORDS: Polyaniline / Micro/nanocomposites / Conductivity / Magnetization / Dielectric Constant /
\end{abstract}

Recently, micro/nanotubes or micro/nanowires have attracted considerable attention because of their unique properties and promising potential applications in nanodevices. ${ }^{1-4}$ Conducting polymer as molecular wires (mico/nanowires) is an excellent choice because of their long $\pi$-conjugation length as well as their high metal conductivity $\left(10^{3}-10^{5} \mathrm{~S} / \mathrm{cm}\right){ }^{5}$ Among conducting polymers, polyaniline (PAni) and its analogues as micro/nanowires have been studied most extensively because their good environmental stability in both doped and undoped forms, low cost and ease of preparation, excellent physical and chemical properties, unique doping mechanism and its ease of protonic acid doping in the emeraldine form. ${ }^{6,7}$

A series of up to date methods have been reported for synthesizing micro-/nanotubes of conducting polymers, such as template synthesis, electrospining, chiral nematic reaction and molecular beam deposition. ${ }^{8,9}$ However, template free method is an excellent route to synthesize the micro/nanotubes of conducting polymers because the micelle consists of dopant or dopant/aniline salt could act as a "soft template" in the formation of the nanostructured PAni by omitting the using of "hard template" (e.g. $\mathrm{Al}_{2} \mathrm{O}_{3}$ or polycarbonate). This method is easy and cheap due to the controllable diameter and length of the micro/nanotubes by alternating the synthesis parameters such as the types of dopants, polymerization temperature used and etc. ${ }^{10-12}$

Electromagnetic radiation is one of the byproduct of rapid development in space technology, navigation, telecommunications, aircraft technology and rapid proliferation of electronic devices. These rapid development and proliferation have generated pollution in the form of electromagnetic interference (EMI). ${ }^{13}$ Generally, the active components commonly used in the traditional microwave absorbing and shielding material are dielectric and magnetic materials. Extensive study has been carried out to develop microwave-absorption materials and shielding materials with high efficiency. High conductivity, magnetic permeability and dielectric permmitivity of the materials contribute to high EMI shielding efficiency (SE) and good microwave absorbing property. ${ }^{14}$ Thus, it is really a challenge to tailoring the synthesis parameters or additives used in order to synthesize a new series of PAni micro/ nanowires possessing moderate conductivity, magnetic and dielectric properties.

The focus of this work is to develop and characterize a PAni micro/nanomaterial exhibits moderate conductivity, magnetic and dielectric properties. Recently, PAni/napthalene sulphonic acid $/ \mathrm{Fe}_{3} \mathrm{O}_{4}$ nanocomposite was reported to exhibit good magnetic properties, ${ }^{15}$ whereby $\mathrm{PAni} / \mathrm{HCl} / \mathrm{TiO}_{2}$ nanocomposite was also reported to show a large dielectric constant. ${ }^{16}$ Hence, PAni/Dopant $/ \mathrm{TiO}_{2} / \mathrm{Fe}_{3} \mathrm{O}_{4}$ nanocomposite should be an excellent microwave absorbing and shielding material because $\mathrm{TiO}_{2}$ and $\mathrm{Fe}_{3} \mathrm{O}_{4}$ used in this study are the dielectric and magnetic filler that could enhance the dielectric and

Graduate School of Human Sensing and Functional Sensor Engineering, Graduate School of Science and Engineering, Yamagata University, 4-3-16 Jonan, Yonezawa Yamagata 992-8510, Japan

*To whom correspondence should be addressed (Tel: +81-23-826-3051, Fax: +81-23-826-3051, E-mail: kuramoto@yz.yamagata-u.ac.jp). 
magnetic property of the PAni. Besides that, hexanoic acid used is the dopant which could improve the conductivity of the PAni. However, the preparation and characterization of such composite have not reported yet.

In this study, as a nano-material possessing moderate conductivity, magnetic property and dielectric property, novel hexanoic acid doped PAni (PAni/HA) micro/nanocomposites containing $\mathrm{TiO}_{2}$ and $\mathrm{Fe}_{3} \mathrm{O}_{4}\left(\mathrm{PAni} / \mathrm{HA} / \mathrm{TiO}_{2}\right.$ and PAni/HA/ $\mathrm{TiO}_{2} / \mathrm{Fe}_{3} \mathrm{O}_{4}$ ) were prepared by template free method using ammonium persulfate, APS as an oxidizing agent under various polymerization conditions. At the starting point of this research, weak acid such as hexanoic acid (HA) was chosen as a dopant because the acidity of the dopant will strongly effect the magnetization of the composites. Besides that, $\mathrm{Fe}_{3} \mathrm{O}_{4}$ microparticles was used instead of $\mathrm{Fe}_{3} \mathrm{O}_{4}$ nanoparticles because the spin magnet of $\mathrm{Fe}_{3} \mathrm{O}_{4}$ nanoparticles could not well align but just keep vibrating. These phenomena finally reduce the magnetization of $\mathrm{Fe}_{3} \mathrm{O}_{4}$ nanoparticles $(\mathrm{Ms}=65 \mathrm{emu} / \mathrm{g})^{8}$ compared with $\mathrm{Fe}_{3} \mathrm{O}_{4}$ microparticles $(\mathrm{Ms}=87 \mathrm{emu} / \mathrm{g}$ ) that used in this study. PAni micro/nanocomposites were then characterized by FT/IR, X-ray diffraction (XRD) and thermogravimetric (TGA) analysis. Morphology studies of the micro/nanocomposites were investigated via SEM. Besides that, conductivity, magnetic and dielectric behaviors of the micro/nanocomposites were being studied in this communication.

\section{EXPERIMENTAL}

Aniline (Ani), n-hexanoic acid (HA) and ammonium peroxydisulfate (APS) used in this study were purchased from Kanto Chemicals. Tri-iron tetra-oxide microparticles $\left(\mathrm{Fe}_{3} \mathrm{O}_{4}\right)$ with particle size of $1 \mu \mathrm{m}$ (purity $99 \%$ ) and $\mathrm{TiO}_{2}$ nanoparticles with particle size of $30 \mathrm{~nm}$ were ordered from Soekawa Chemicals and Tayca Corporation respectively. The crystal phase of $\mathrm{TiO}_{2}$ used this study is in anatase form because it is economical and anatase form of $\mathrm{TiO}_{2}$ easily dispersed in water based systems or aqueous systems. Water used for polymerization was purified by distillation. Other reagents were used as received without purification unless noted.

In this study, hexanoic acid doped polyaniline (PAni/HA) micro/nanocomposites containing $\mathrm{TiO}_{2}$ and $\mathrm{Fe}_{3} \mathrm{O}_{4}$ (PAni/HA/ $\mathrm{TiO}_{2}$ and $\mathrm{PAni} / \mathrm{HA} / \mathrm{TiO}_{2} / \mathrm{Fe}_{3} \mathrm{O}_{4}$ ) were prepared by template free method using APS as an oxidizing agent under various polymerization conditions.

First, HA $\left(1.0 \times 10^{-2} \mathrm{~mol}\right)$ and Ani $\left(1.0 \times 10^{-2} \mathrm{~mol}\right)$ were mixed vigorously in distilled water for $30 \mathrm{~min}$. Then, $0.10 \mathrm{~g}$ of $\mathrm{TiO}_{2}$ (nanoparticles, $30 \mathrm{~nm}$ ) and $0.10 \mathrm{~g}$ of $\mathrm{Fe}_{3} \mathrm{O}_{4}$ (microparticles, $1 \mu \mathrm{m}$ ) were added into the solution under sonication in order to obtain an emulsion of Ani/HA complex containing $\mathrm{TiO}_{2}$ and $\mathrm{Fe}_{3} \mathrm{O}_{4}$. The emulsion of Ani/HA complex containing $\mathrm{TiO}_{2}$ and $\mathrm{Fe}_{3} \mathrm{O}_{4}$ was mixed vigorously under ultrasonic action for $4 \mathrm{~h}$ to disperse $\mathrm{TiO}_{2}$ and $\mathrm{Fe}_{3} \mathrm{O}_{4}$ well into the Ani/HA mixture before polymerization. APS aqueous solution was added dropwise in the mixture at $0{ }^{\circ} \mathrm{C}$ within $2 \mathrm{~h}$. The Ani/HA/ APS ratio used is $1 / 1 / 1$. After addition of APS, the mixture was stirred under sonication for $1 \mathrm{~h}$. Polymerization was continued (undisturbed) for $12 \mathrm{~h}$ by maintaining the temperature at $0{ }^{\circ} \mathrm{C}$ in the ice bath. The micro/nanocomposites were washed with distilled water and methanol three times, respectively. The nanocomposites were then dried in vacuum for $24 \mathrm{~h}$.

The same polymerization method was repeated for PAni/ $\mathrm{HA}$, PAni/HA/ $/ \mathrm{TiO}_{2}$ and $\mathrm{PAni} / \mathrm{HA} / \mathrm{TiO}_{2} / \mathrm{Fe}_{3} \mathrm{O}_{4}$ micro/nanocomposite (with and without $\mathrm{TiO}_{2}$ and $\mathrm{Fe}_{3} \mathrm{O}_{4}$ ) at room temperature (considered as $25^{\circ} \mathrm{C}$ ).

The characterizations of the PAni micro/nanocomposites were carried out by FT/IR, XRD, thermogravimetric analysis (TGA) and SEM. The FT/IR measurements in $\mathrm{KBr}$ in discus shape were taken by Shimadzu FT/IR (type $8100 \mathrm{M}$ ) spectrometer in between $400-4000 \mathrm{~cm}^{-1}$. The X-ray diffraction patterns of the PAni micro/nanocomposite were recorded using RINT2000 Wilder-angle goniometer using $\mathrm{Cu} \mathrm{K} \alpha$ radiation. Thermograms of the PAnis were recorded using MettlerToledo 851 thermogravimetric analyzer, in the presence of $\mathrm{N}_{2}$ atmosphere from room temperature to $600{ }^{\circ} \mathrm{C}$ with heating rate of $10^{\circ} \mathrm{C} / \mathrm{min}$. Particles sizes and morphology behaviors of the PAni micro/nanocomposite were determined from scanning electron microscope, SEM (JSM-6300F).

Samples used for conductivity measurements were in discus shape form with diameter of $10 \mathrm{~mm}$ and thickness of $0.3-$ $0.5 \mathrm{~mm}$. The sample was compressed slowly using a constant load of $100 \mathrm{~kg}$ and the whole process took around $5-10 \mathrm{~min}$. Samples obtained with compacted density of $1.09 \times 10^{3} \mathrm{~kg} / \mathrm{m}^{3}$ were tested using a standard four-probe method (model Loresta $\mathrm{HP})$.

The relative dielectric constants $\left(\varepsilon_{\mathrm{r}}\right)$ are obtained from the measurements of capacitance (C) and dissipation factor (D) by a 4192A LF Yokogawa Howlett Packard impedance analyzer in the frequency range of $5 \mathrm{~Hz}$ to $13 \mathrm{MHz}$. Samples used for the measurement were in discus shape that coated with the silver paste. The role of the silver paste is as the electrical contacts during measurement. The permittivity of the material is evaluated by the relation $\mathrm{C}=\varepsilon \mathrm{s}^{\prime} \mathrm{A} / \mathrm{t}$, in which $\mathrm{t}$ is the thickness of the samples and $\mathrm{A}$ is the area of the discus shape's surface. The relative dielectric constant, $\varepsilon_{\mathrm{r}}$ is calculated from $\varepsilon_{\mathrm{r}}=\varepsilon_{\mathrm{s}}{ }^{\prime} / \varepsilon_{\mathrm{o}}$

Magnetization of PAni samples at magnetic field from $-1.0 \times 10^{4} \mathrm{Oe}$ to $1.0 \times 10^{4} \mathrm{Oe}$ were measured at room temperature by vibrating sample magnetometer (VSM), model 1660 signal processor.

\section{RESULTS AND DISCUSSION}

The FT/IR spectra of PAni/HA, PAni/HA/TiO ${ }_{2}$ and PAni/HA/ $\mathrm{TiO}_{2} / \mathrm{Fe}_{3} \mathrm{O}_{4}$ micro/nanocomposites are shown in Figure 1. The peaks at $1572 \mathrm{~cm}^{-1}$ and $1497 \mathrm{~cm}^{-1}$ are representing the quinoid and bezenoid ring, while the peaks at $1300 \mathrm{~cm}^{-1}$ and $1248 \mathrm{~cm}^{-1}$ are indicating the C-N stretching vibration of PAni. The peak at $1148 \mathrm{~cm}^{-1}$ is due to quinoid unit of doped-PAni. The stretching of $\mathrm{CH}_{3}$ and $\mathrm{CH}_{2}$ at $2928 \mathrm{~cm}^{-1}$ and $2853 \mathrm{~cm}^{-1}$ as well as the vibration mode of $\mathrm{C}=\mathrm{O}$ at $1750 \mathrm{~cm}^{-1}$ are corresponding to the HA that used as the dopant 


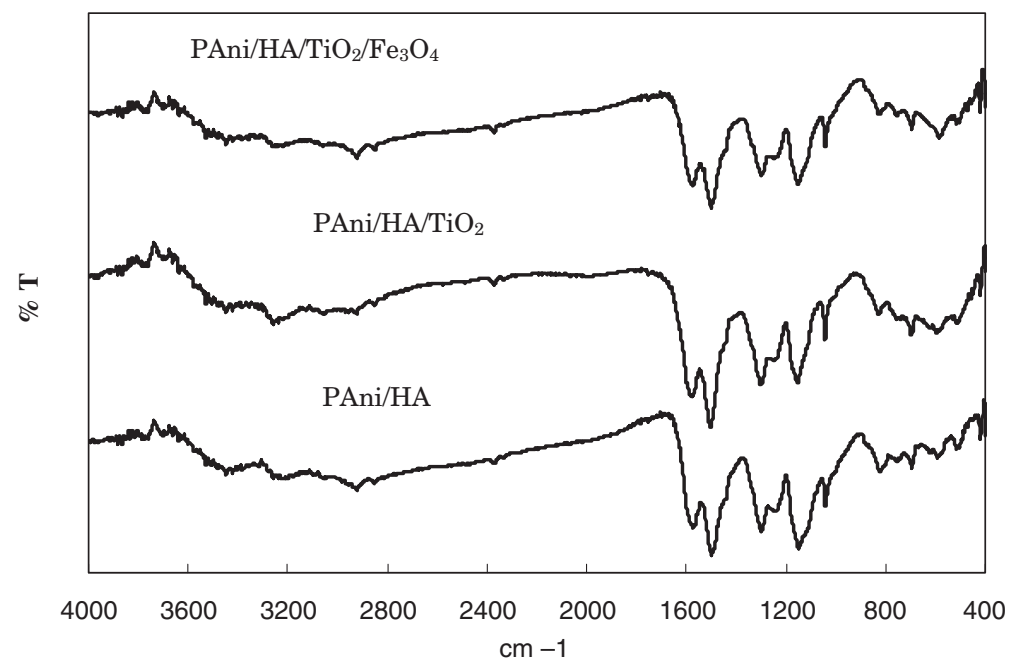

Figure 1. $\mathrm{FT} / \mathrm{IR}$ spectra of $\mathrm{PAni} / \mathrm{HA}, \mathrm{PAni} / \mathrm{HA} / \mathrm{TiO}_{2}$ and $\mathrm{PAni} / \mathrm{HA} / \mathrm{TiO}_{2} / \mathrm{Fe}_{3} \mathrm{O}_{4}$ micro/nanocomposites.

in this study. ${ }^{9}$ The peaks that mentioned above existed in all PAni/HA, PAni/HA/TiO 2 and PAni/HA/TiO $2 / \mathrm{Fe}_{3} \mathrm{O}_{4}$ micro/ nanocomposites that synthesized during this study. For PAni/ $\mathrm{HA} / \mathrm{TiO}_{2} / \mathrm{Fe}_{3} \mathrm{O}_{4}$ micro/nanocomposite, the band at $598 \mathrm{~cm}^{-1}$ is attributed to the presence of the $\mathrm{Fe}_{3} \mathrm{O}_{4} \cdot{ }^{17}$ The incorporation of $\mathrm{TiO}_{2}$ in the nanocomposites leads to small shift of FT/IR peaks in the nanocomposites. ${ }^{16}$

The X-ray diffraction patterns of the PAni micro/nanocomposite were recorded by Wilder-angle goniometer using $\mathrm{Cu} \mathrm{K} \alpha$ radiation. Refer to the X-ray diffraction patterns shown in Figure 2, PAni/HA showed amorphous behavior with three major peaks for the characterization of doped-PAni. The peak at $2 \theta=7.0^{\circ}$ is ascribed to the periodicity distance between the HA dopant and $\mathrm{N}$ atom of PAni on adjacent main chains of PAni/HA. However, the peaks at $2 \theta=20.3^{\circ}$ and $25.0^{\circ}$ are assigned as the periodicity parallel and perpendicular of the chain direction of the PAni chains. ${ }^{9}$ On the other hand, both $\mathrm{PAni} / \mathrm{HA} / \mathrm{TiO}_{2}$ \& $\mathrm{PAni} / \mathrm{HA} / \mathrm{TiO}_{2} / \mathrm{Fe}_{3} \mathrm{O}_{4}$ micro/nanocomposites indicated the presence of $\mathrm{TiO}_{2}$ as predicted by the peaks belong to $\mathrm{TiO}_{2}$ such as $2 \theta=25.3^{\circ}$ and $48.0^{\circ} .{ }^{18,19}$ In the PAni micro/nanocomposite, the crystal phase of the $\mathrm{TiO}_{2}$ is not

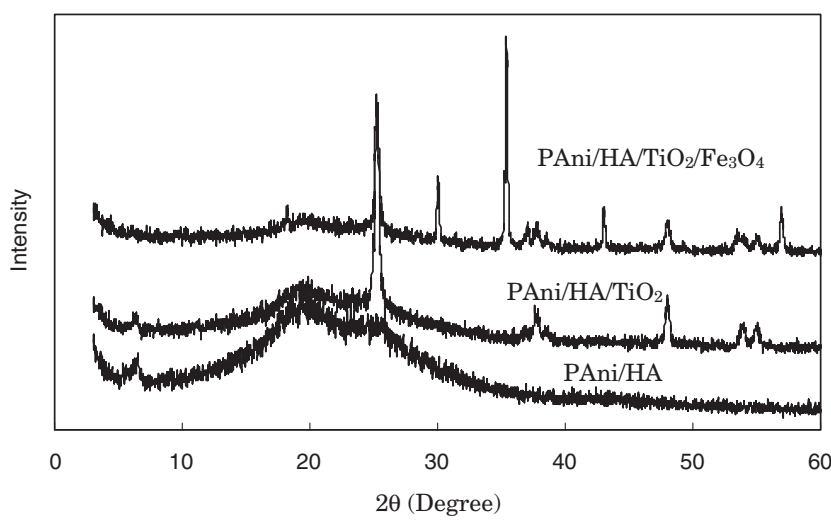

Figure 2. X-Ray diraction patterns of $P A n i / H A, P A n i / H A / T i O_{2}$ and $P A n i / H A /$ $\mathrm{TiO}_{2} / \mathrm{Fe}_{3} \mathrm{O}_{4}$ micro/nanocomposites. changed because the characteristic peaks of $\mathrm{TiO}_{2}$ are remained the same even after polymerization as shown by the X-ray diffraction patterns. Furthermore, the existence of $\mathrm{Fe}_{3} \mathrm{O}_{4}$ in $\mathrm{PAni} / \mathrm{HA} / \mathrm{TiO}_{2} / \mathrm{Fe}_{3} \mathrm{O}_{4}$ micro/nanocomposites was also determined by the peaks belong to $\mathrm{Fe}_{3} \mathrm{O}_{4}$ such as $2 \theta=35.4^{\circ}, 30.1^{\circ}$, $18.3^{\circ}, 43.1^{\circ}$ and $57.0^{\circ} .20,21$

The thermal stability of PAni micro/nanocomposites were recorded by using thermogravimetric analysis. The thermogram obtained is shown in Figure 3 from room temperature to $600^{\circ} \mathrm{C}$. In TGA profile of PAni micro/nanocomposites, major losses of weight were observed over four temperature periods. Generally, the first decrease of weight loss from room temperature to $100{ }^{\circ} \mathrm{C}$ is attributed to the evaporization of water molecules or moistures and also the loss of possible impurities such as remaining monomer. The second stage observed from $100{ }^{\circ} \mathrm{C}$ to $230{ }^{\circ} \mathrm{C}$ is due to the loss of the HA dopant from PAni chains. The third stage from $230^{\circ} \mathrm{C}$ to $350{ }^{\circ} \mathrm{C}$ is responsible for the dedoping of HA dopant from backbone of PAni. Finally, the last stage observed from $340^{\circ} \mathrm{C}$ onwards is attributed to the complete degradation and structural decomposition of PAni. In the temperature range of $100{ }^{\circ} \mathrm{C}$ to $350{ }^{\circ} \mathrm{C}$, the weight loss of $\mathrm{PAni} / \mathrm{HA} / \mathrm{TiO}_{2}$ is greater than PAni/HA while $\mathrm{PAni} / \mathrm{HA} / \mathrm{TiO}_{2} / \mathrm{Fe}_{3} \mathrm{O}_{4}$ is more thermally stable than PAni/HA and $\mathrm{PAni} / \mathrm{HA} / \mathrm{TiO}_{2}$. It can be explained by the fact that a strong interaction exists at interface of $\mathrm{TiO}_{2}$ and PAni weakens the interactive force of PAni interchains and finally fasten the thermal decomposition of PAni in the composites. ${ }^{22}$ However, existence of $\mathrm{Fe}_{3} \mathrm{O}_{4}$ in the mico/ nanocomposites significantly enhanced the interactive force of PAni chain and also the interaction between PAni with $\mathrm{TiO}_{2}$, thus improved the thermal stability of the PAni/HA/ $/ \mathrm{TiO}_{2} /$ $\mathrm{Fe}_{3} \mathrm{O}_{4}$ mico/nanocomposites if compared with mico/nanocomposites without addition of $\mathrm{Fe}_{3} \mathrm{O}_{4}$. The contents of $\mathrm{Fe}_{3} \mathrm{O}_{4}$ in $\mathrm{PAni} / \mathrm{HA} / \mathrm{TiO}_{2} / \mathrm{Fe}_{3} \mathrm{O}_{4} \mathrm{mico} /$ nanocomposites synthesized at $0{ }^{\circ} \mathrm{C}$ are higher $(25 \%)$ compared with synthesized at $25^{\circ} \mathrm{C}$ $(10 \%)$ as indicated by the TGA profile below. Although the mass of $\mathrm{Fe}_{3} \mathrm{O}_{4}$ adding into the $\mathrm{PAni} / \mathrm{HA} / \mathrm{TiO}_{2} / \mathrm{Fe}_{3} \mathrm{O}_{4}$ mico/ 


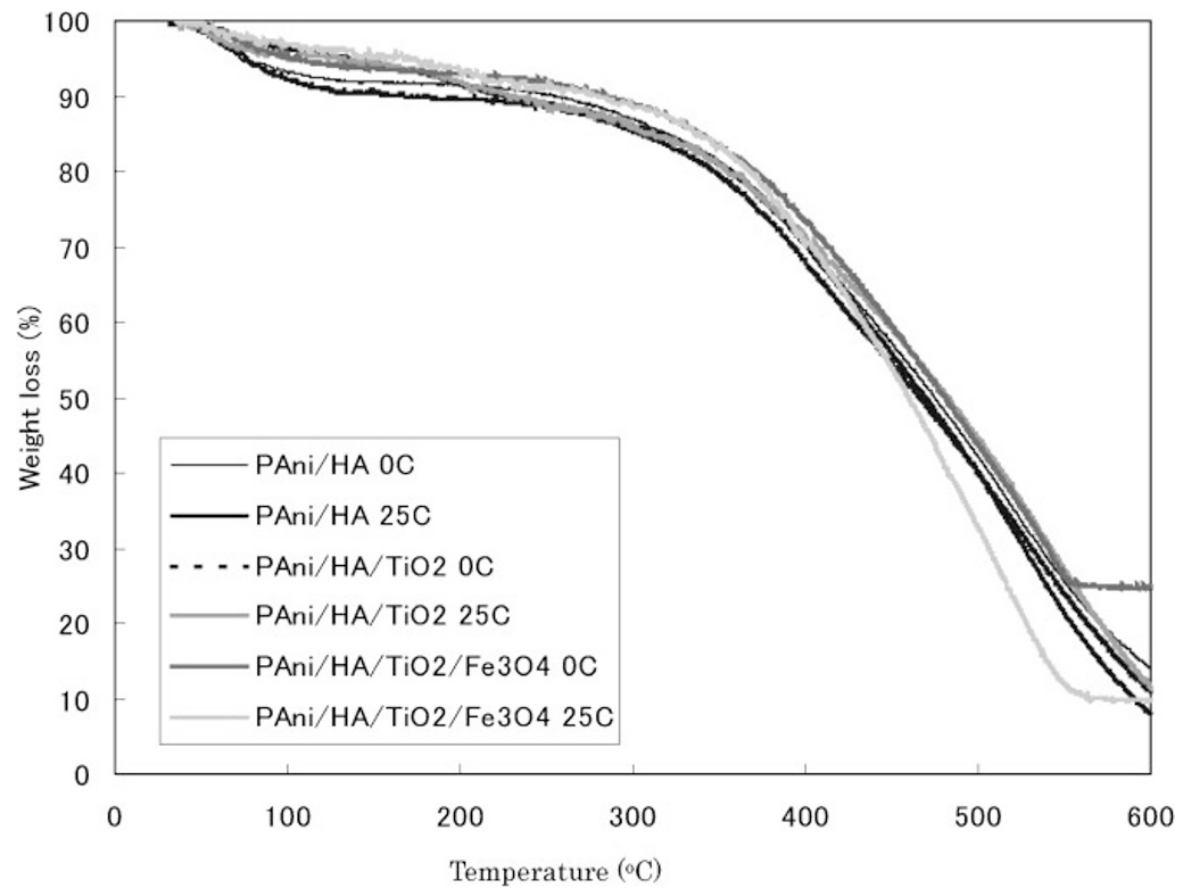

Figure 3. Thermograms of $\mathrm{PAni} / \mathrm{HA}, \mathrm{PAni} / \mathrm{HA} / \mathrm{TiO}_{2}$ and $\mathrm{PAni} / \mathrm{HA} / \mathrm{TiO}_{2} / \mathrm{Fe}_{3} \mathrm{O}_{4}$ micro/nanocomposites.

nanocomposites synthesized at $0{ }^{\circ} \mathrm{C}$ and $25^{\circ} \mathrm{C}$ is same $(0.1 \mathrm{~g})$, $\mathrm{Fe}_{3} \mathrm{O}_{4}$ could easily interact with PAni to form the PAni/HA/ $\mathrm{TiO}_{2} / \mathrm{Fe}_{3} \mathrm{O}_{4}$ mico/nanocomposites at low temperature $\left(0^{\circ} \mathrm{C}\right)$ compared with high temperature $\left(25^{\circ} \mathrm{C}\right)$. This fact also can be proved by the magnetization data.

SEM images shown in Figure 4 indicated that $\mathrm{Fe}_{3} \mathrm{O}_{4}$ and $\mathrm{TiO}_{2}$ micro/nanoparticles used in this study are ball-like shapes with diameter of $1 \mu \mathrm{m}$ and $30 \mathrm{~nm}$, respectively. During template free method, micelle composed of Ani/HA or Ani/ $\mathrm{HA} / \mathrm{TiO}_{2}$ salt act as a "soft template" in order to form of the PAni nanotubes/rods (Figure 5). $\mathrm{TiO}_{2}$ nanoparticles is believed to be existed in the center of the Ani/HA micelle to form the nanorods/tubes. On the other hand, Ani is assigned as the shell due to the hydrophobility of Ani and HA is acted as the tail of the micelles due to the hydrophilicity of $-\mathrm{COOH}$ of HA dopant. Since there is repulsive interactions of the "tail" group (HA group) of the micelle, thus the micelles are exist as a fluid surface and the spherical micelles are expected to form through aggregation process first before the formation of nanorods/ tubes (through elongation) or spheres (through accretion) due to the lowest surface energy. Polymerization of these nanocomposites might take place in the micelle/water interface because APS oxidant used is water soluble. The micells become big sphere by accretion or tubes/rods by elongation depend on the synthesis conditions during polymerization process. For example, during template free method, polymerization of Ani/dopant under stirring process might form the PAni spheres, however, polymerization of Ani/dopant under undisturbed state might form the nanorods/tubes. ${ }^{9}$

Nanorods/tubes that shown in the morphology below indicated that PAni/HA, PAni/HA/ $\mathrm{TiO}_{2}$ and PAni/HA/ $\mathrm{TiO}_{2} / \mathrm{Fe}_{3} \mathrm{O}_{4}$ micro/nanocomposites exhibited polymerization

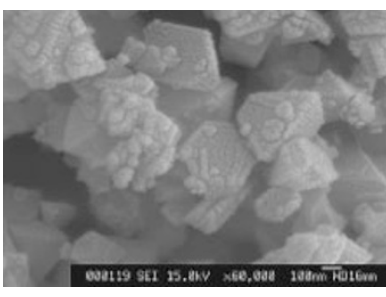

(a)

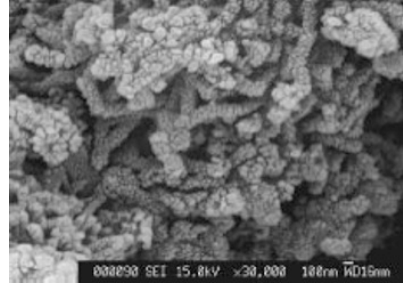

(c)

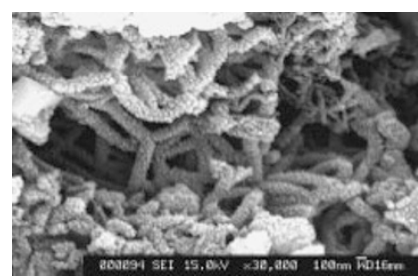

(e)

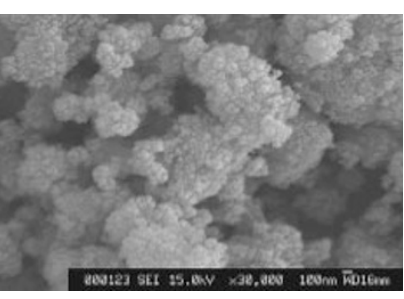

(b)

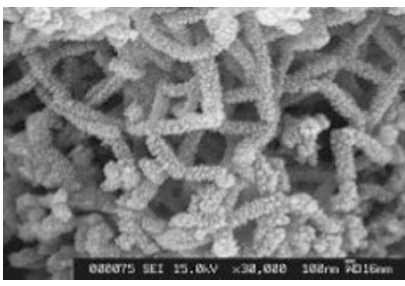

(d)
Figure 4. $\mathrm{SEM}$ images of (a) $\mathrm{Fe}_{3} \mathrm{O}_{4}$ microparticles (60,000x magnification), (b) $\mathrm{TiO}_{2}$ nanoparticles $\left(30,000 x\right.$ magnification) (c) PAni/HA, $0^{\circ} \mathrm{C}$ (30,000x magnification) (d) $\mathrm{PAni} / \mathrm{HA} / \mathrm{TiO}_{2}, 0^{\circ} \mathrm{C}$ mico/nanocomposites (30,000x magnification) and (e) $\mathrm{PAni} / \mathrm{HA} / \mathrm{TiO}_{2} / \mathrm{Fe}_{3} \mathrm{O}_{4}, 0^{\circ} \mathrm{C}$ micro/nanocomposite (30,000x magnification). 

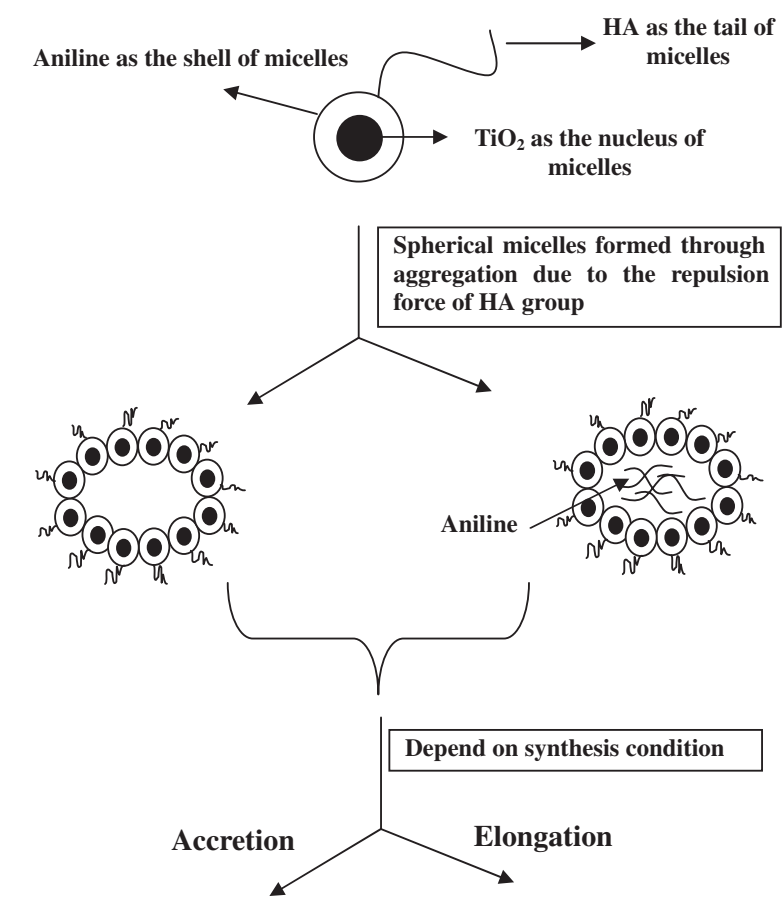

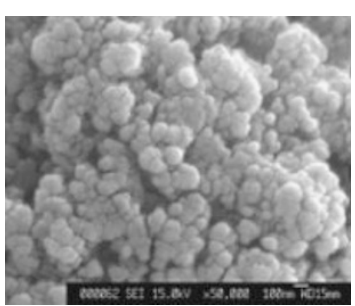

Spheres

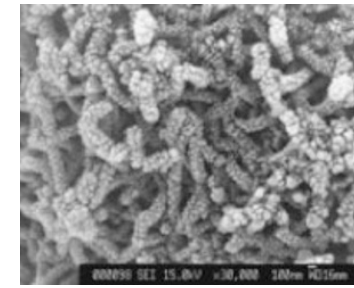

Nanorods/tubes
Figure 5. Schematic images for the formation of PAni spheres or PAni nanorods/tubes from the $\mathrm{Ani} / \mathrm{HA} / \mathrm{TiO}_{2}$ micelle.

through elongation. As shown in Figure 6, the micelle filled with aniline will form the nanorods while the micelle without aniline will form the nanotubes. The nanorods/tubes obtained in this study are formed by the Ani/HA micelles with $\mathrm{TiO}_{2}$ as nucleus and Ani/HA micelles without $\mathrm{TiO}_{2}$ as nucleus. So, the formations of the nanorods/tubes are not just depend on the $\mathrm{TiO}_{2}$ content in the nanocomposites. The Ani/HA/ $\mathrm{TiO}_{2}$ micelle mechanism that proposed here agreed with the Ani/ salicyclic acid/ $\mathrm{TiO}_{2}$ micelle mechanism that reported by Zhang et al. ${ }^{11}$

$\mathrm{Fe}_{3} \mathrm{O}_{4}$ microparticles are physically mixed with the PAni/ $\mathrm{HA} / \mathrm{TiO}_{2}$ nanotubes/rods to form the PAni/HA/TiO $/ \mathrm{Fe}_{3} \mathrm{O}_{4}$ micro/nanocomposites (Figure 7). The diameter of PAni/HA nanorods/tubes increased from $150-180 \mathrm{~nm}$ to $180-200 \mathrm{~nm}$ (PAni/HA/TiO 2 \& PAni/HA/ $/ \mathrm{TiO}_{2} / \mathrm{Fe}_{3} \mathrm{O}_{4}$ ) after addition of $\mathrm{Fe}_{3} \mathrm{O}_{4}$ and $\mathrm{TiO}_{2}$. PAni/HA, PAni/HA/TiO 2 and PAni/HA/ $\mathrm{TiO}_{2} / \mathrm{Fe}_{3} \mathrm{O}_{4}$ nanocomposites synthesized at $0{ }^{\circ} \mathrm{C}$ resulted large amount of nanorods/tubes compared with synthesized at $25^{\circ} \mathrm{C}$. It is because polymerization of nanocomposites at low temperature proceeded slowly and could form the nanorods/tubes easily compared with nanocomposites synthesized at higher temperature.

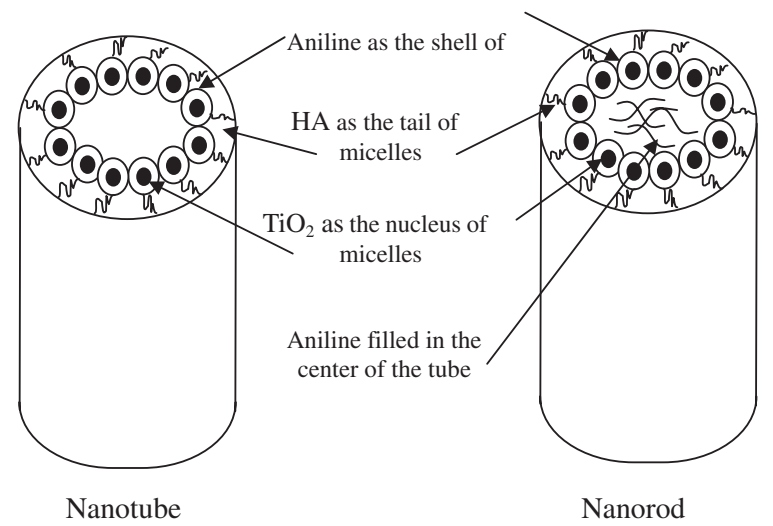

Figure 6. Schematic images for the resulted $\mathrm{PAni} / \mathrm{HA} / \mathrm{TiO}_{2}$ nanorods/tubes through template free synthesis.

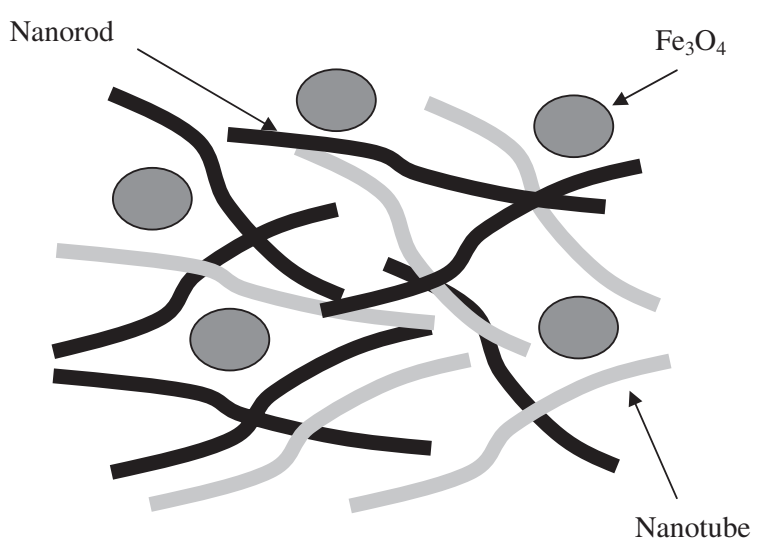

Figure 7. Schematic image of $\mathrm{Fe}_{3} \mathrm{O}_{4}$ physically mixed with $\mathrm{PAni} / \mathrm{HA} / \mathrm{TiO}_{2}$ nanorods/tubes during template free synthesis.

Refer to the SEM images in Figure 6, PAni/HA/ $\mathrm{TiO}_{2}$ resulted large amount of nanorods/tubes after addition of $\mathrm{TiO}_{2}$ but the amount of nanorods/tubes significantly reduced after addition of $\mathrm{Fe}_{3} \mathrm{O}_{4}$. It is because addition of $\mathrm{TiO}_{2}$ in the center of the Ani/HA micelle during template free method could activate the formation of nanorods.tubes. However, addition of $\mathrm{Fe}_{3} \mathrm{O}_{4}$ act as the barrier that disturbed the formation of the PAni nanorods/tubes from the Ani/HA micelles and thus reduced the amount of nanorod/tubes. In this situation, some of the micelles become big sphere (such as globular or ellipsoidal shapes) by accretion instead of elongation. Based on the results that discussed above, it is reasonable to convince that the morphology (amount of nanorods/tubes) and sizes of nanostructures (diameter of nanorods/tubes) are essentially affected by the synthesis parameter such as polymerization temperature and types of filler used. This result also agreed with the results that reported by Zhang et al. and Wan et al. in which the formation of the nanostructures are significantly depend on the synthesis condition such as reaction temperature, types of filler or dopant, concentration of dopant used and so on. ${ }^{9,23}$

Electrical conductivities of PAni/HA, PAni/HA/TiO 2 and $\mathrm{PAni} / \mathrm{HA} / \mathrm{TiO}_{2} / \mathrm{Fe}_{3} \mathrm{O}_{4}$ micro/nanocomposites were recorded 
Table I. Conductivities, relative dielectric constant $\left(\boldsymbol{\varepsilon}_{\mathrm{r}}\right)$ and magnetization (Saturated magnetization (Ms), remnant magnetization (Mr) and coercive force $(\mathrm{Hc})$ ) of PAni/HA, PAni/HA/TiO 2 and $\mathrm{PAni} / \mathrm{HA} / \mathrm{TiO}_{2} / \mathrm{Fe}_{3} \mathrm{O}_{4}$ micro/nanocomposite synthesized at $0^{\circ} \mathrm{C}$ and $25^{\circ} \mathrm{C}$

\begin{tabular}{lccccc}
\hline Sample Name & $\begin{array}{c}\text { Conductivity } \\
(\mathrm{S} / \mathrm{cm})\end{array}$ & $\varepsilon_{\mathrm{r}}$ & $\begin{array}{c}\mathrm{Ms} \\
(\mathrm{emu} / \mathrm{g})\end{array}$ & $\begin{array}{c}\mathrm{Mr} \\
(\mathrm{emu} / \mathrm{g})\end{array}$ & $\begin{array}{c}\mathrm{Hc} \\
(\mathrm{Oe})\end{array}$ \\
\hline $\mathrm{PAni} / \mathrm{HA}\left(0^{\circ} \mathrm{C}\right)$ & $1.0 \times 10^{-3}$ & - & - & - & - \\
$\mathrm{PAni} / \mathrm{HA}\left(25^{\circ} \mathrm{C}\right)$ & $7.0 \times 10^{-4}$ & - & - & - & - \\
$\mathrm{PAni} / \mathrm{HA} / \mathrm{TiO}_{2}\left(0^{\circ} \mathrm{C}\right)$ & $4.2 \times 10^{-4}$ & -5952 & - & - & - \\
$\mathrm{PAni} / \mathrm{HA} / \mathrm{TiO}_{2}\left(25^{\circ} \mathrm{C}\right)$ & $8.0 \times 10^{-4}$ & 2633 & - & - & - \\
$\mathrm{PAni} / \mathrm{HA} / \mathrm{TiO}_{2} / \mathrm{Fe}_{3} \mathrm{O}_{4}\left(0^{\circ} \mathrm{C}\right)$ & $3.3 \times 10^{-4}$ & -7381 & 7.7 & $9.2 \times 10^{-1}$ & 122.7 \\
$\mathrm{PAni} / \mathrm{HA} / \mathrm{TiO}_{2} / \mathrm{Fe}_{3} \mathrm{O}_{4}\left(25^{\circ} \mathrm{C}\right)$ & $4.9 \times 10^{-4}$ & 1234 & 4.7 & $5.4 \times 10^{-1}$ & 121.6 \\
$\mathrm{Fe}_{3} \mathrm{O}_{4}$ & - & - & 87.4 & 13.0 & 124.7 \\
\hline
\end{tabular}

using four-probe method and the data were shown in Table I. Base on the data obtained, PAni/HA polymerized at low temperature exhibited higher conductivity $\left(1.0 \times 10^{-3} \mathrm{~S} / \mathrm{cm}\right)$ compared with PAni/HA polymerized at higher temperature $\left(7.0 \times 10^{-4} \mathrm{~S} / \mathrm{cm}\right)$. The conductivities of the PAni/HA/ $/ \mathrm{TiO}_{2}$ and $\mathrm{PAni} / \mathrm{HA} / \mathrm{TiO}_{2} / \mathrm{Fe}_{3} \mathrm{O}_{4}$ micro/nanocomposites were relatively low $\left(3.3-4.2 \times 10^{-4} \mathrm{~S} / \mathrm{cm}\right)$ after addition of $\mathrm{TiO}_{2}$ and $\mathrm{Fe}_{3} \mathrm{O}_{4}$. During this study, $\mathrm{TiO}_{2}$ and $\mathrm{Fe}_{3} \mathrm{O}_{4}$ that encapsulated in the PAni/HA matrix will partially block the PAni conductive path along the backbone of the PAni and lead to the decreasing in conductivity.

The relative dielectric constant $\left(\varepsilon_{\mathrm{r}}\right)$ (at $2.5 \mathrm{MHz}$ ) of PAni/ $\mathrm{HA} / \mathrm{TiO}_{2} \& \mathrm{PAni} / \mathrm{HA} / \mathrm{TiO}_{2} / \mathrm{Fe}_{3} \mathrm{O}_{4}$ micro/nanocomposite synthesized at $0{ }^{\circ} \mathrm{C}$ and $25^{\circ} \mathrm{C}$ were recorded in Table I below. As a result, $\varepsilon_{\mathrm{r}}$ of $\mathrm{PAni} / \mathrm{HA} / \mathrm{TiO}_{2} \& \mathrm{PAni} / \mathrm{HA} / \mathrm{TiO}_{2} / \mathrm{Fe}_{3} \mathrm{O}_{4}$ micro/nanocomposite synthesized $25^{\circ} \mathrm{C}$ is 2633 and 1234 respectively. Generally, the dielectric constants of polymers are very low and the addition of high dielectric constant material could significantly enhance the dielectric constant of polymeric systems. Recently, it had been found that large dielectric constant could be achieved near the percolation threshold of the composite. ${ }^{24}$ The micro/nanocomposites that synthesized in this study consists of three materials that possessing different conductivities and permittivities. Thus, the interface across PAni/HA with $\mathrm{TiO}_{2}$ and $\mathrm{Fe}_{3} \mathrm{O}_{4}$ may be sources that leading the large dielectric constant that posses by $\mathrm{PAni} / \mathrm{HA} / \mathrm{TiO}_{2}$ \& $\mathrm{PAni} / \mathrm{HA} / \mathrm{TiO}_{2} / \mathrm{Fe}_{3} \mathrm{O}_{4}$ micro/nanocomposite synthesized $25^{\circ} \mathrm{C} .{ }^{16}$ As reported by Chandrasekhar \& Naishadham (1999), the high values of the dielectric constant are characteristics of conducting polymers which are partially attributed by the disordered motion of the charge carriers along the backbone of the conjugated polymer. ${ }^{25}$

On the other hand, $\varepsilon_{\mathrm{r}}$ of $\mathrm{PAni} / \mathrm{HA} / \mathrm{TiO}_{2}$ and PAni/HA/ $\mathrm{TiO}_{2} / \mathrm{Fe}_{3} \mathrm{O}_{4}$ micro/nanocomposite synthesized $0{ }^{\circ} \mathrm{C}$ is -5952 and -7381 respectively. The unique properties of so-called "left-handed" materials (LHM) with simultaneously negative real parts of the dielectric permmitivity $\left(\varepsilon_{\mathrm{r}}{ }^{*}=\varepsilon_{\mathrm{r}}{ }^{\prime}-\mathrm{j} \varepsilon_{\mathrm{r}}{ }^{\prime \prime}\right)$ and magnetic permeability $\left(\mu_{\mathrm{r}}{ }^{*}=\mu_{\mathrm{r}}{ }^{\prime}-\mathrm{j} \mu_{\mathrm{r}}{ }^{\prime \prime}\right)$, (including the possibility of focusing the radiation of point sources by a plane-parallel plate) were predicted by Prof. V.G. Veselago in late $1960 .{ }^{26}$ After that, various options were suggested for the practical realization of several types of composites with negative values of $\varepsilon_{\mathrm{r}}{ }^{\prime}$ and $\mu_{\mathrm{r}}{ }^{\prime}$. Although the negative dielectric constant is a new discovery in physic since year 2000 but the mechanism of this material is still not clear. ${ }^{27-29}$ Negative value of dielectric constant will give rise to minimum transmission and maximum absorption that indicated good microwave absorbing property as reported by Smith et al. (2000). ${ }^{30}$ Since the negative value of dielectric constant is a new discovery in physic since year 2000 and the mechanism of this material is still not clear, it is very difficult to explain why the negative dielectric constant is obtained at lower synthesis temperature instead of positive value.

Table I show the magnetization data on the applied magnetic field (from $-10 \mathrm{kOe}$ to $10 \mathrm{kOe}$ ) of $\mathrm{Fe}_{3} \mathrm{O}_{4}$ microparticles, $\mathrm{PAni} / \mathrm{HA} / \mathrm{TiO}_{2} / \mathrm{Fe}_{3} \mathrm{O}_{4}$ nanocomposites synthesized at $0{ }^{\circ} \mathrm{C}$ and $25^{\circ} \mathrm{C}$. All the magnetization data recorded in Table I are saturated magnetization (Ms), remnant magnetization (Mr) and coercive force $(\mathrm{Hc})$ that estimated from the magnetization curves. PAni/HA/ $/ \mathrm{TiO}_{2} / \mathrm{Fe}_{3} \mathrm{O}_{4}$ micro/nanocomposite $\left(25^{\circ} \mathrm{C}\right)$ under applied magnetic field at room temperature exhibited the hysteric loops (Figure 8) of the ferromagnetic behavior with the moderate saturation magnetization $(\mathrm{Ms}=4.7 \mathrm{emu} / \mathrm{g})$ and high coercivity $(\mathrm{Hc}=121.6$ $\mathrm{Oe})$. Refer to all magnetization curves obtained, hysteresis loop appeared in $\mathrm{Fe}_{3} \mathrm{O}_{4}$ as well as $\mathrm{PAni} / \mathrm{HA} / \mathrm{TiO}_{2} / \mathrm{Fe}_{3} \mathrm{O}_{4}$ nanocomposites synthesized at $0{ }^{\circ} \mathrm{C}$ and $25^{\circ} \mathrm{C}$ that indicated PAni/ $\mathrm{HA} / \mathrm{TiO}_{2} / \mathrm{Fe}_{3} \mathrm{O}_{4}$ nanocomposites show similar ferromagnetic behavior as $\mathrm{Fe}_{3} \mathrm{O}_{4}$ used in this study. For $\mathrm{Fe}_{3} \mathrm{O}_{4}$ microparticles, $\mathrm{Ms}, \mathrm{Mr}$ and $\mathrm{Hc}$ are $87.4 \mathrm{emu} / \mathrm{g}, 13.0 \mathrm{emu} / \mathrm{g}$ and $124.7 \mathrm{Oe}$ respectively. PAni/HA/ $\mathrm{TiO}_{2} / \mathrm{Fe}_{3} \mathrm{O}_{4}$ nanocomposites synthesized at $0{ }^{\circ} \mathrm{C}$ exhibited higher magnetization ( $\mathrm{Ms}=7.73$ emu/g) compared with nanocomposites that synthesized at $25^{\circ} \mathrm{C}(\mathrm{Ms}=4.67 \mathrm{emu} / \mathrm{g})$. As conclusion, PAni/HA/TiO $/$ $\mathrm{Fe}_{3} \mathrm{O}_{4}$ nanocomposites synthesized at $0^{\circ} \mathrm{C}$ shows stronger magnetic behavior compared with synthesized at $25^{\circ} \mathrm{C}$. These phenomena can be explained by the fact that $\mathrm{Fe}_{3} \mathrm{O}_{4}$ could easily interact with PAni to form the PAni/HA/ $/ \mathrm{TiO}_{2} / \mathrm{Fe}_{3} \mathrm{O}_{4}$ mico/nanocomposites at low temperature $\left(0^{\circ} \mathrm{C}\right)$ compared with high temperature $\left(25^{\circ} \mathrm{C}\right)$ even the mass of $\mathrm{Fe}_{3} \mathrm{O}_{4}$ adding into both samples is same $(0.1 \mathrm{~g})$. This fact could be proved by the TGA profile discussed before.

\section{CONCLUSIONS}

In this communication, PAni/HA, PAni/HA/TiO 2 and $\mathrm{PAni} / \mathrm{HA} / \mathrm{TiO}_{2} / \mathrm{Fe}_{3} \mathrm{O}_{4}$ were successfully synthesized through template free method under various polymerization conditions. FT/IR spectra of PAni/HA/TiO 2 and PAni/HA/ $/ \mathrm{TiO}_{2} / \mathrm{Fe}_{3} \mathrm{O}_{4}$ indicated the peaks are derived from HA doped PAni. The $\mathrm{X}$ ray diffraction patterns of $\mathrm{PAni} / \mathrm{HA} / \mathrm{TiO}_{2}$ and $\mathrm{PAni} / \mathrm{HA} /$ $\mathrm{TiO}_{2} / \mathrm{Fe}_{3} \mathrm{O}_{4}$ micro/nanocomposites clearly showed the existence of both $\mathrm{TiO}_{2}$ and $\mathrm{Fe}_{3} \mathrm{O}_{4}$. Thermal stability of the micro/ nanocomposites was being studied by TGA analysis. Nanorods/tubes shown in the SEM images indicated that PAni/HA, $\mathrm{PAni} / \mathrm{HA} / \mathrm{TiO}_{2}$ and $\mathrm{PAni} / \mathrm{HA} / \mathrm{TiO}_{2} / \mathrm{Fe}_{3} \mathrm{O}_{4}$ micro/nanocomposites exhibited polymerization through elongation. The diameters of PAni/HA nanorods/tubes increased from 150 $180 \mathrm{~nm}$ to $180-200 \mathrm{~nm}\left(\mathrm{PAni} / \mathrm{HA} / \mathrm{TiO}_{2}\right.$ and $\mathrm{PAni} / \mathrm{HA} / \mathrm{TiO}_{2} /$ 


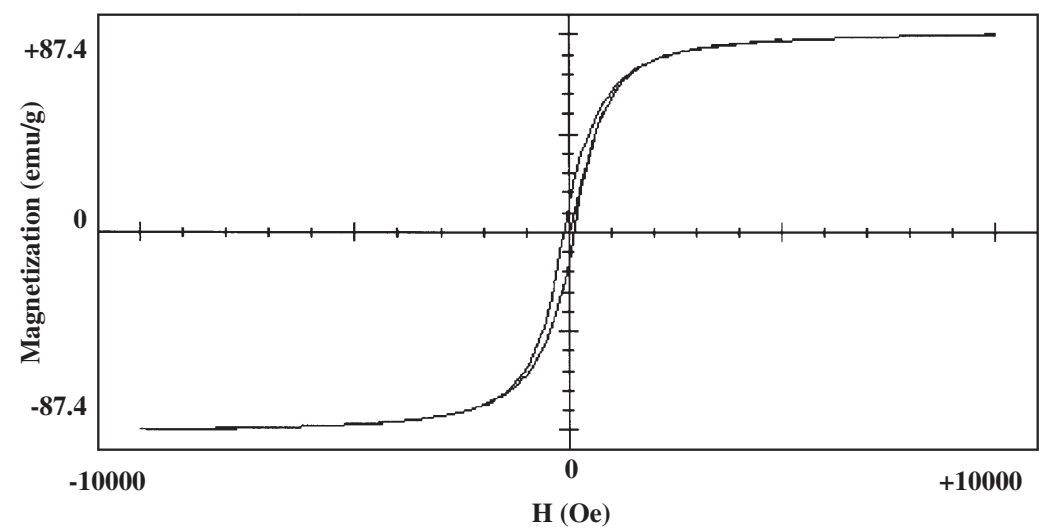

(a)

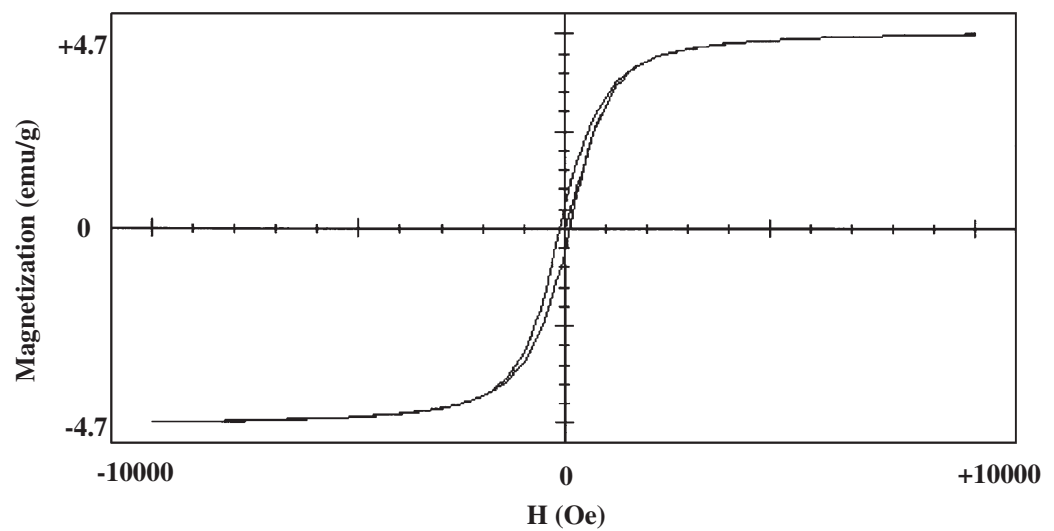

(b)

Figure 8. Variation of magnetization with the applied magnetic field measured at room temperature for (a) $\mathrm{Fe}_{3} \mathrm{O}_{4}$ and (b) $\mathrm{PAni} / \mathrm{HA}^{\mathrm{TiO}} 2 / \mathrm{Fe} \mathrm{O}_{4} \mathrm{micro} /$ nanocomposite synthesized at $25^{\circ} \mathrm{C}$.

$\left.\mathrm{Fe}_{3} \mathrm{O}_{4}\right)$ after addition of $\mathrm{Fe}_{3} \mathrm{O}_{4}$ and $\mathrm{TiO}_{2}$. PAni/HA, PAni/ $\mathrm{HA} / \mathrm{TiO}_{2}$ and $\mathrm{PAni} / \mathrm{HA} / \mathrm{TiO}_{2} / \mathrm{Fe}_{3} \mathrm{O}_{4}$ micro/nanocomposites synthesized at $0^{\circ} \mathrm{C}$ resulted large amount of nanorods/tubes compared with those synthesized at $25^{\circ} \mathrm{C}$. PAni/HA polymerized at low temperature exhibited higher conductivity $\left(1.0 \times 10^{-3} \mathrm{~S} / \mathrm{cm}\right)$ compared with PAni/HA polymerized at higher temperature $\left(7.0 \times 10^{-4} \mathrm{~S} / \mathrm{cm}\right)$. The conductivities of the PAni/HA/ $\mathrm{TiO}_{2}$ and $\mathrm{PAni} / \mathrm{HA} / \mathrm{TiO}_{2} / \mathrm{Fe}_{3} \mathrm{O}_{4}$ micro/nanocomposites were relatively low $\left(3.3-4.2 \times 10^{-4} \mathrm{~S} / \mathrm{cm}\right)$ after addition of $\mathrm{TiO}_{2}$ and $\mathrm{Fe}_{3} \mathrm{O}_{4}$ due to the blocking of conductive pathways by $\mathrm{TiO}_{2}$ and $\mathrm{Fe}_{3} \mathrm{O}_{4}$ that embedded in the PAni matrix. Besides that, magnetic and dielectric behaviors of the micro/nanocomposites were measured by using vibrating sample magnetometer (VSM) and impedance analyzer respectively. As a result, $\varepsilon_{\mathrm{r}}$ of $\mathrm{PAni} / \mathrm{HA} / \mathrm{TiO}_{2} \& \mathrm{PAni} / \mathrm{HA} / \mathrm{TiO}_{2} /$ $\mathrm{Fe}_{3} \mathrm{O}_{4}$ micro/nanocomposite synthesized $25^{\circ} \mathrm{C}$ is 2633 and 1234 respectively. By contrast, $\varepsilon_{\mathrm{r}}$ of $\mathrm{PAni} / \mathrm{HA} / \mathrm{TiO}_{2}$ and $\mathrm{PAni} / \mathrm{HA} / \mathrm{TiO}_{2} / \mathrm{Fe}_{3} \mathrm{O}_{4}$ micro/nanocomposite synthesized $25^{\circ} \mathrm{C}$ is -5952 and -7381 respectively. $\mathrm{PAni} / \mathrm{HA} / \mathrm{TiO}_{2} /$ $\mathrm{Fe}_{3} \mathrm{O}_{4}$ micro/nanocomposites synthesized at $0^{\circ} \mathrm{C}$ exhibited higher magnetization $(\mathrm{Ms}=7.7 \mathrm{emu} / \mathrm{g})$ compared with micro/nanocomposites that synthesized at $25^{\circ} \mathrm{C}(\mathrm{Ms}=4.7$ $\mathrm{emu} / \mathrm{g}$ ). As conclusion, PAni/HA/ $/ \mathrm{TiO}_{2} / \mathrm{Fe}_{3} \mathrm{O}_{4}$ micro/nanocomposites that posses moderate conductivity, high dielectric constant (or negative dielectric constant) and high magnetization that contribute to high EMI shielding efficiency (SE) and good microwave absorbing property have been successfully synthesized.

Acknowledgment. The author would like to show high appreciation for the Japan Government Scholarship (Monbukagakusho) for the financial support. Magnetization measurements were made at Laboratory Ishii and dielectric measurements were tested at Laboratory Hirose in Yamagata University. The authors would like to show acknowledgment to Professor Osamu Ishii and Professor Seiji Hirose for their kindly discussion and advice. Besides that, author would like to thanks Mr. Masaki Nakamura for the measurement of magnetization.

Received: May 21, 2007 Accepted: September 25, 2007 Published: November 13, 2007

\section{REFERENCES}

1. A. R. Hopkins, R. A. Lipeles, and W. H. Kao, Thin Solid Films, 447448, 474 (2004).

2. B. J. Kim, S. G. Oh, M. G. Han, and S. S. Im, Synth. Met., 122, 297 
(2001).

3. M. G. Han, S. K. Cho, S. G. Oh, and S. S. Im, Synth. Met., 126, 53 (2002).

4. S. J. Su and N. Kuramoto, Synth. Met., 114, 147 (2000).

5. Z. Zhang and M. Wan, Synth. Met., 128, 83 (2002).

6. Y. Duan, S. Liu, and H. Guan, Sci. Tech. Adv. Mater., 6, 513 (2005).

7. S. K. Dhawan, N. Singh, and D. Rodrigues, Sci. Tech. Adv. Mater., 4, 105 (2003).

8. Y. Long, Z. Chen, J. L. Duvail, Z. Zhang, and M. Wan, Physica B, 370, 121 (2005).

9. L. Zhang, L. Zhang, M. Wan, and Y. Wei, Synth. Met., 156, 454 (2006).

10. Y. Long, Z. Chen, N. Wang, Z. Zhang, and M. Wan, Physica B, 325, 208 (2003)

11. L. Zhang, M. Wan, and Y. Wei, Synth. Met., 151, 1 (2005).

12. M. Wan, J. Liu, H. Qiu, J. Li, and S. Li, Synth. Met., 119, 71 (2001).

13. S. Geetha, K. K. Satheesh Kumar, and D. C. Trivedi, Compos. Sci. Technol., 65, 973 (2005).

14. C. Y. Lee, H. G. Song, K. S. Jang, E. J. Oh, A. J. Epstein, and J. Joo, Synth. Met., 102, 1346 (1999).

15. Z. Zhang and M. Wan. Synth. Met., 132, 205 (2003).

16. A. Dey, S. De, A. De, and S. K. De, Nanotechnology, 15, 1277 (2004).

17. A. Chen, H. Wang, B. Zhao, and X. Li, Synth. Met., 139, 411 (2003).
18. D. Zhong, J. J. Moore, B. M. Mishra, T. Ohno, E. A. Levashov, and J. Disam, Surf. Coat. Technol., 163-164, 50 (2003).

19. S. H. Lu and C. W. Chung, Mater. Lett., 46, 149 (2000).

20. Y. K. Sun, M. Ma, Y. Zhang, and N. Gu, Colloids Surf., A, 245, 15 (2004).

21. K. Shalini, G. N. Subbanna, S. Chandrasekaran, and S. A. Shivashankar, Thin Solid Films, 424, 56 (2003).

22. I. S. Lee, J. Y. Lee, J. H. Sung, and H. J. Choi, Synth. Met., 152, 173 (2005).

23. M. Wan, Z. Wei, Z. Zhang, L. Zhang, K. Huang, and Y. Yang, Synt. Met., 135-136, 175 (2003).

24. C. Huang, Q. M. Zhang, and J. Su, Apply. Phys. Lett., 82, 3502 (2003).

25. P. Chandrasekhar and K. Naisdham, Synth. Met., 105, 115 (1999),

26. V. G. Veselago, Sov. Phys. Usp. 10509 (1968).

27. A. N. Lagarkov, V. N. Semenenko, V. A. Chistyaev, D. E. Ryabov, S. A. Tretyakov, and C. R. Simovski, Electromagnetics, 17, 213 (1997).

28. A. N. Lagarkov, V. N. Semenenko, V. N. Kisel, and V. A. Chistyaev, J. Magn. Magn. Mater., 258-259, 161 (2003).

29. G. V. Eleftheriades, A. K. Iyer, and P. C. Kremer, IEEE Trans. Microwave Theory Tech. 50, 2702 (2002).

30. D. R. Smith, W. J. Padilla, D. C. Vier, S. C. Nemat-Nasser, and S. Schultz, Phys. Rev. Lett., 84, 4184 (2000). 